\title{
Charlotte Wolff 's Contribution to Bisexual History and to (Sexuality) Theory and Research: A Reappraisal for Queer Times
}

\author{
Toni Brennan and Peter Hegarty \\ University of Surrey
}

\begin{abstract}
The concept of bisexuality has suffered from the same dilemma as that Of reality. So much has been said and assumed about both, that the words symbolizing them have become more and more mechanically used, and therefore misused.
\end{abstract}

-Charlotte Wolff, lecture to the South Place ethical Society,

29 November 1977

At the December 2006 conference of the Lesbian and gay Psychology Section of the British Psychological Society, bisexual activist and academic Ron Fox (who is currently compiling an archive of Bisexuality resources in Amsterdam) reported that in the late seventies, as an enthusiastic graduate student who wanted to research bisexuality, he found very few resources. "There was Charlotte Wolff and little else,” he reflected, reiterating the importance he had ascribed elsewhere to her work. ${ }^{1}$ In fact, already in the midseventies there was a heightened interest in bisexuality both in the general press and in academia. Time and Newsweek published articles on so-called bisexual chic in May 1974. Margaret Mead, having long witnessed and described (as an anthropologist) "bisexual" behavior in non-Western cultures, lamented in Redbook magazine that Western culture imposed a "straight jacket" on bisexuality. ${ }^{2}$ At around the same time, sociologists Philip Blumstein and Pepper Schwartz carried out a series of interview-based studies with people who identified as bisexual. ${ }^{3}$ In View from Another Closet, Janet Bode argued that reductive dichotomous thinking that could not or would not contemplate bisexuality was at the root of the erroneous identification of the poet Sappho with "lesbianism" (from Lesbos, the island where she lived). ${ }^{4}$ The convenient disregard of the love poems Sappho dedicated to men, Bode argued, had resulted in the elision of the poet's bisexuality from accounts of her life and work. In 1976 Maggi Rubenstein and Harriet Leve founded the San Francisco Bisexual Centre. during the same year, Fritz Klein was developing the Klein Sexual Orientation grid and working on his book The Bisexual Option, eventually published in 1978, a few months after Bisexuality, Wolff's theoretical and empirical investigation. ${ }^{6}$

Yet, pace Fox, there is no mention of Wolff 's contribution in Angelides's A History of Bisexuality. ${ }^{7}$ Merl Storr, in her critical reader of writings on bisexuality from Freud to Kaloski, mentions Wolff only in passing, to deplore her ambiguous stance: she argues that Wolff at times seemed to conceptualize bisexuality as a mixture of "masculinity" and "femininity" rather than treating it as "a combination or co-existence of heterosexuality and homosexuality." Clare Hemmings, for whom the contested territories of "masculinity" and "femininity" are central to shaping Bisexual Spaces (albeit with premises different from Wolff 's, and writing after the explosion of queer theory), 
acknowledges Wolff as a key figure in the mid- to late seventies' resurgence of interest in bisexuality after the long post-Kinsey silence but does not otherwise engage with her work. ${ }^{9}$ Storr's criticism of Wolff 's ambiguity seems justified in the light of Bisexuality's juxtapositions, contradictions, and rhetorical claims - a book declaredly rooted in phenomenology but arguably poised between the remnants of a psychoanalytic framework, phenomenology, and more traditional scientific discourse. Perhaps it is Bisexuality's contradictions that make it difficult to contextualize within what seem to be the overarching narratives of current bi scholarship: can queer theory help to theorize bisexuality, or does it subtly operate elision under an ostensibly inclusive umbrella? ${ }^{10}$ Yet, years before any mention of "queer theory," Wolff's Bisexuality foreshadowed this very dilemma. ${ }^{11}$

Some recent histories and theories of bisexuality go considerably back in history to discuss and deploy Sigmund Freud, Havelock Ellis, and Wilhelm Stekel as sine qua non in bisexual scholarship, whatever their "fortune" in present times, but no similar use is made of Wolff 's work. ${ }^{2}$ Yet it can be argued that it is through the book's very tensions and contradictions as well as through the debates surrounding its publication that it "speaks" to presentday social scientists and activists across three decades about the production and the "storying" of sexual identities, about the challenges posed by bisexuality to binary, "orientation-focused" ways of thinking sexuality, and about the contested status of science. The (albeit at times contradictory) phenomenological basis of Wolff 's endeavor is particularly interesting in light of the current turn to phenomenology in the humanities, including some cutting-edge work in queer theory, and in the recent rise of phenomenologyinspired research methodologies. ${ }^{13}$ Thus, Bisexuality arguably predated many issues and developments that are very cogent to- day, and it is not only for researchers and historians of (bi)sexuality that a "forgetting" of this work would be, to say the least, remiss.

\section{Bisexuality - The Study}

Charlotte Wolff (1897-1986) was an independent scholar who worked in the United Kingdom; she was aware of the surge of attention to sexuality and gender in the sixties and seventies, and she was also acquainted with past literature on these topics. She had trained and worked as a physician in Weimar Germany (having also studied philosophy with Edmund Husserl and Martin Heidegger). When the Nazi regime came to power, because she was Jewish, she was relieved of her duties in the Berlin Health Service. In 1933 she escaped to Paris, where she conducted research in chirology (holistic personality assessment based on hand patterns) and was acquainted with the surrealists and other artists and writers, including Aldous Huxley and his wife, Maria. With the Huxleys' help, in 1936 she left Paris for London, where she lived and worked for the rest of her life. She reported these events in her first autobiography, published in 1969, in which she also stated that she knew very early in life that she was attracted to women, and she described many of her attachments and relationships. ${ }^{14}$ At the end of the sixties, Wolff-a fellow of the British Psychological Society (BPS) working mainly as a psychotherapist in private practice-embarked on an extensive theoretical and empirical investigation of lesbianism, which was published in book form in 1971 as Love between 
Women. ${ }^{15}$ For this study Wolff surveyed and interviewed many participants who, although they identified as "lesbian," were or had been married or in relationships with men. in other words, they engaged in bisexual behavior. This finding led Wolff to consider investigating bisexuality, especially as she found that "a clear-cut definition of bisexuality has not been given by those who used the concept for the purpose of explaining other sexual variations" and "no large-scale study on the subject itself has ever been attempted."16

The first paragraph of Bisexuality defines the book as a sequel to Wolff 's study on lesbianism and contends that "homosexuality has its roots in bisexuality." ${ }^{\prime 7}$ Later, when reflecting on her sexological research in her second autobiography, Wolff stated that there is a case for considering human beings as primarily bisexual, "with homosexuality and heterosexuality as secondary developments, like branches growing out of a tree." She also stated that one inspiration for her research on lesbianism had been feminism, having realized, "long before Women's Liberation came into being, that feminism was inseparable from lesbianism." ${ }^{\prime 18}$ it can be argued, as this quotation also underlines, that Wolff lived as a feminist without being part of any "movement" - she was, as noted, an independent scholar-but, at the end of the sixties, when she began her research, there was an interesting convergence between Wolff 's life in the spirit of feminist principles, so to speak, and the then Zeitgeist, the rise of second-wave feminism.

For Love between Women Wolff had recruited 108 lesbian participants mainly from sexual minority organizations and through their publications, devised and administered a questionnaire, asked respondents to complete an "emotional autobiography," and conducted interviews. One hundred and fifteen heterosexual-identified women acted as a "control” group. For Bisexuality, Wolff also recruited participants from lesbian and gay-friendly organizations, from advertisements in "socially progressive" publications, and through personal recommendations. ${ }^{19}$ She used "a three-pronged approach": questionnaires, biographical sketches (including diaries), and interviews. ${ }^{20}$

There were seventy-five female and seventy-five male participants in the investigation, and three examples of interviews, seven biographical sketches, and two diaries were included in the first edition, published in 1977. in a long appendix, one descriptive table (showing occupation details for participants and their parents) and thirty statistical tables summarized the questionnaire data.

Wolff stated that "we don't really know objectively what we are-and worse, who we are-due to brain-washing processes." Noting the "subjective nature of psychosexual identity," she advertised for individuals "who thought of themselves as bisexual." Her advertisements hinted at the tentativeness or reluctance she anticipated on the part of prospective participants in claiming a (bi)sexual identity outside of binaries. Wolff argued that "far more people are used to thinking of themselves as homo- than bisexuals because, in contrast to bisexuality, homosexuality is more easily defined. Bisexuals are not only less conspicuous but more elusive than homosexuals. Some use tactics of mimicry in order to be indistinguishable from 'ordinary' citizens, and I was apprehensive that they might have misgivings about participating in a study of a controversial nature."21 
Participants first completed the questionnaire devised by Wolff and sent her an "autobiographical sketch" together with the questionnaire or later, before meeting her for an interview. She saw the questionnaires "as an illustration rather than an explanation of the material," their main advantage being that "they reveal at a glance the findings communicated in the text," although "the meat of the procedure lay in autobiographies and interviews."22

As was the case with Love between Women, by publishing in book form, Wolff had the opportunity not only to include an in-depth theoretical background with an extensive and up-to-date literature review on the subject but also to present long passages from the qualitative data and to enable her readers to construct their own account of these narratives (to a certain extent). The autobiographical sketches and diaries constitute roughly one third of the book. Wolff reported that, not long after collecting the first few questionnaires and autobiographical sketches and conducting the first interviews, she "realized that considerable differences existed between male and female bisexuals," which she found "of great interest." ${ }^{23}$ Following this insight, she subjected the questionnaire data to statistical analysis for sex differences and integrated the results with the findings from the qualitative data.

Consistent with her occasional caveats about "objectivist” social science, Wolff stressed the importance of the interaction with participants and of the reciprocity of the relationship; she preceded the first interview in the book with these reflections: "Opening the door to a stranger and seeing a face for the first time, is a mild shock experience. One never knows how one is going to be affected by the visitor, and vice versa. First meetings of importance affect me like a caresse or a blow. First impressions can be decisive for the outcome of an interview." Wolff acknowledged a certain unique- ness, an imponderable quality to each interview: "An overall impression which is intuitive goes beyond conscious awareness. it can be compared to a portrait which reveals simultaneously the whole of a person, while description in words can only be piecemeal, in the sequence of time.” ${ }^{24}$ She reported that her intuitive impression of her interviewee Mrs. B., when the participant stood at her doorstep, was of "remarkable vitality ... . [and] zest for life under a thin veil of shyness" and sensed that the positive impression must have been mutual, "because she appeared to relax at once and seemed eager to answer my questions.” So, far from attempting to "partial out" any interpersonal "noise," Wolff did not shy away from words such as "intuitive," and she recognized the interaction and synergy of researcher and participant, in line with a phenomenological perspective. ${ }^{25}$ Yet at times she offered strikingly "objectivist” accounts of some participants' development and personality, or she selectively availed herself of some topoi of psychoanalysis while rejecting others, in particular to explain early influences on subsequent adult behavior. Reporting on the finding that early relationships with one's parents affect future relationships, Wolff asserted that all intimate adult relationships always regress to childhood patterns, citing Freud, Melanie Klein, and Carl Jung to shore up her argument.

According to Wolff, the women in her study were more secure and mature than the men. She stated that they appeared to be "stronger than men in having the courage of their convictions" as regards their attraction to both sexes and that they were "more independent of public opinion.",26 
While women tended to see bisexuality as an extension of homoemotionality (a term she had coined), some men experienced their attraction to other men with emotional conflict due to "anxiety about their manliness" and fear of stigma. $^{27}$ This conclusion was consistent with Blumstein and Schwartz's findings published in the same year and with the popular view, still widespread more than thirty years later, that homosexual identity or homosexual behavior implies impaired masculinity. ${ }^{28}$ Wolff noted that the women she studied had never suffered the humiliation that criminalization of homosexual behavior in Britain had caused to men and, furthermore, that "the mimicry of a normal family life, more plausible in bi- than homosexual women, afforded some of them a certain protection” against the stigma and discrimination to which lesbians were routinely subjected. ${ }^{29}$

The autobiographies and interviews further led Wolff to conclude that women tended to be emotionally independent from their husbands or male lovers, while some of the older male respondents who were married "regarded their wives as a combination of mother and house-keeper.” A number of younger men who had been exposed to feminist ideas through their female partners were determined not to fall into traditional gender roles, as exemplified by the autobiography of "Charles" in her study. Among younger respondents, "experimenting" with more partners and also bringing up children collectively were recurring features. in general, though, very few men (whether belonging to an older or younger generation) were open with their wives about their "homosexual side." In contrast, women tended to be more open with their husbands or male partners, and in a few cases their female lover was included in a ménage à trois. Wolff observed that "not many men could believe that another woman could drive them out of the marriage bed, except those who actually experienced it," which she ascribed to "the idea of male superiority [being] deeply ingrained in the minds of most men.” Also, lesbian partners of bisexual women would often be jealous, an insecurity due to fear that their lovers ultimately might prefer a man. Furthermore, radical lesbians would disapprove of bisexual women for "“copping out' of their homosexual responsibilities by letting the side down, [when] actually [they] . . . had done nothing of the sort." ${ }^{30}$ in fact, the idea of the bisexual woman as traitor of the lesbian political project, as recent research has chronicled, has survived well beyond the seventies. ${ }^{31}$

Thus, anticipating current research, Wolff concluded that, in general, bisexuals-be they female or male- "live in a twilight world," not fully accepted by heterosexuals and accused of hypocrisy by homosexuals. Wolff 's position, and, arguably, the main "message" of the book, is that "disharmony within the ranks of sexual variations" based on the policing of territorial boundaries, while understandable, is "against their own interest...and destructive" and that the homo/heterosexual binary supports the hetero-sexist society of which it is the product: "Society has categorized people according to their sexual orientation, and has never understood that there is only human sexuality with manifold expressions. It has given heterosexuality pride of place, and has made other sexual orientations look ugly...Only in a bisexual society can human beings get rid of the sexual compartments in which they are entrenched, and understand that we are all in the same boat, only in different 
attire." Wolff envisaged an egalitarian society "with no exclusive claims made for either sex" and believed that it would be possible only with a "bisexual" society, whereby "bisexuality" would not necessarily be a sexual identity that translates into a bisexual lifestyle but rather the potential that enables individuals to understand and respect those who are "in different attire." 32 In this light, Wolff 's call for a "bisexual" society can be seen as a disruption of the "directional" conceptualization of sexuality and therefore a disruption of the discourse of "orientation," which, as Matthew Waites has subsequently highlighted, is "directional" by definition and enshrines either an elision of bisexuality (not predicated on directionality/orientation) or an oxymoron ("bisexual orientation”). ${ }^{33}$

\section{Reception of Bisexuality}

The publication of Bisexuality sparked a debate that brought to the fore many contested assumptions about “doing 'science"” and academic research, about authority and agency, and about "legitimacy" of topics and methods of investigation. Wolff 's claim that "the atom bomb will destroy us all if we do not achieve...a bisexual society" was much ridiculed in a very negative review of the book by the psychoanalyst John Padel that was published at the beginning of February 1978 by the BBC-sponsored cultural weekly the Listener. Padel questioned the book's scientific value-implicitly constructing "scientific value" as the standard to judge by_even if "at first sight [it seemed] scientifically planned.” In particular, using Wolff 's own caveat as regards "personal and intimate data," he argued that, although the questionnaire data were subjected to statistical analysis, little reliability could be expected, especially of data "about the content of dreams and fantasies, and about the number and nature of casual sexual contacts." ${ }^{34}$ As to the nine autobiographical sketches, Padel highlighted that the longest was "nearly 20 pages of extracts from an American call-girl's diaries," adding that "only one of the writers appears to be a person capable of more than a shallow relationship" and expressing doubt that these sketches could support any other idea but that "her chosen subjects have very restricted and sometimes disturbed personalities.”35 In Bisexuality, Wolff had subverted the normative, unspoken assumptions underlying this critique-assumptions about who is (not) allowed to speak, the link between authorship and authority, what counts as a "proper" relationship (and what does not). Wolff had described the call girl's (Ingrid's) contribution as "unique because she is not only a great lover of men and women, but has a special knowledge of 'sex' through her profession,” which singled out Ingrid's situated knowledge without judgment, or implicit appeals to the reader, or use of discourses of victimhood. ${ }^{36}$

The following week the magazine published a brief reply by Wolff in the letters page stating that the review was "so twisted that it would be futile to answer him in detail" and pointing out, as correction to "one of several inaccuracies of fact," that the statistical work was undertaken not by herself, as Padel seemed to suggest, but by experts of the department of Psychology, University College, London. ${ }^{37}$ 
In an additional (unpublished) full-length letter to the editor, Wolff strongly defended her phenomenological position, writing that "the premise underlying the whole of my investigation was: that we can only study what people think they are."38 Her rhetoric appealed to the authority of the academic "establishment," highlighting that "this premise was made clear in the book, and wholly agreed to, in fact with approval, by Dr Jonckheere, Senior Lecturer at the department of Psychology, University College, London, and at the Psychological department, University of Geneva.”39

She stated that "all verbal communications between people concerning the mind are of this nature" and cited psychoanalysis, Padel's field, as a prime example. All psychology and psychoanalysis cannot be "strictly scientific," she argued, so Padel's dismissal of her book as "pseudo-scientific" had "no relevance” and simply showed his entrenchment in a passé paradigm: "in itself, science is no longer the 'god' it used to be. The new generation has moved to a far more universal approach to psychology, that is, to an understanding of human beings and their experiences." Furthermore, she deplored the "illtempered tone of the review" and responded to Padel's many other criticisms; for instance, as regards the published interviews' alleged superficiality as psychosexual assessments, she reiterated what she deemed to be sufficiently clear in the book, namely, that the interviews were greatly abbreviated and that their purpose was to provide examples of her interaction with participants in the study. Padel had closed his scathing review by affirming the superiority of heterosexuality, citing its preponderance in most species, a view that Wolff dismissed in her lengthier reply as "out of touch with present-day thinking."40 When, following the publication of her brief response, the Listener published in the next available issue a reader's letter that challenged Padel's views and defended Bisexuality, likening her vision of a "bisexual" society to Marcuse's view of an egalitarian society, Wolff wrote to the editor on the same day, urging him to publish her full response. ${ }^{41}$ Finally, when no such action was undertaken, Wolff professed in a further letter to be "distressed" and asked him "to have another look at the letter, and perhaps find space for it." ${ }^{42}$ In sum, Wolff pursued a contradictory strategy: to secure her place as a bona fide scientific investigator, she deployed the credentials of her expert advisors when responding to reviewers who called into question the scientific value of Bisexuality. Concurrently, she subverted the orthodox meaning of "expert" (as with Ingrid's diary) and criticized the reductionism of the mainstream scientific paradigm. This is not surprising in light of her liminal position as an independent researcher. ${ }^{43}$ Furthermore, it was a strategy in line with what Celia Kitzinger has described as the two discourses employed by liberal, reformist research on sexual minorities during the seventies: the scientific rhetoric of "objectivity" and, to a lesser extent, the "insider" rhetoric that was then gaining increasing credibility. ${ }^{44}$

Wolff's liminal position (highlighted as such by scientific orthodoxy's response to Bisexuality) reveals the tenets, the "ropes" holding up the edifice of “consecrated scientific practice,” as Pierre Bourdieu expressed it, as well as its fault lines. ${ }^{45}$ Even as the dominant ideology_including "liberal" academiaconstructs an "agenda" as something "other," it also constructs in a parallel way the unmarked, neutral norm, understood as objective by virtue of lacking 
the partiality of an "agenda." For instance, in a brief, nine- line review in Counselling News, Francis Taylor called Bisexuality a "useful addition to the still comparatively small literature on the subject" and noted that Wolff "deals both with the biological substratum and the psychological influences on sexual and gender identity and gives extended autobiographical extracts which are of considerable human interest even if not of great scientific value.” ${ }^{, 46}$ Such a short, "briefly noted" kind of review could not go into much detail, but mention of the scientifically inflected "biological substratum" and (to an arguably lesser extent) "psychological influences” conveys the message that Wolff kept to the conventions of scientific inquiry and/or psychological practice-in dealing with these matters, she was (or seemed to be), figuratively speaking, wearing her lab coat and/or holding her analyst's case notes. However, this assessment is contrasted with the autobiographical sketches in which agency is at least shared with participants; this "reduces" the endeavor to "human interest" that, albeit acknowledged as "considerable" in a credit-wherecredit's-due move, "is not of great scientific value” and implicitly subordinated to science, like an interesting footnote. In the final lines of the review, Taylor focused on Wolff 's alleged even greater breach with established and valid "objective" practice: "As is so often the case with women writing on sexual matters, there are areas where Dr Wolff's position regarding women's liberation would seem to influence her views." ${ }^{47}$

Impervious to the critique of patriarchy already articulated by second-wave feminism, notably by Kate Millett, Taylor did not even consider how men writing on sexual matters and men reviewing books written by women might be influenced by their masculinist position. ${ }^{48}$

The Wolff archive shows that, although Wolff kept reviews of her books on file and occasionally wrote to publications if she felt that reviewers had misrepresented her work, Bisexuality was her only work for which she summarized the response to the book and to her lectures and talks on the topic in the typed document "Reactions to Bisexuality." She divided the reviews into positive, negative, and mixed; additionally, she noted letters received and comments made to her, also recording her own responses to such reviews and comments. After what she defined as a "mixed review" and an "odd review" by Sally Vincent in World Medicine, for example, a brief response from Wolff was published in the letters page, focusing on the appropriateness and authoritativeness of the statistical method she had chosen: she stated that "its scientific value was attested" by prestigious specialists and rhetorically asked whether their judgment was "less authoritative than that of Sally Vincent." this case Wolff seems to completely align her position with scientific discourse and mainstream notions of authority. In addition, Wolff wrote a letter to the editor in which she called into question the standard of reviews and, among other errors, deplored that Vincent had "reduced the [nine] unedited autobiographies to 8, and said they were edited." 50 Indeed, in Bisexuality Wolff states that the autobiographies of five women and four men are "for the most part unedited" but does not give any specific details except to say that "Ingrid's" diary had to be shortened. ${ }^{51}$ 


\section{Bisexuality and Representation}

It could be argued that, be they eight or nine, complete or shortened, the published autobiographies had undergone "editing" further upstream, so to speak, by being chosen out of all the 150 presumably available to Wolff. Moreover, it is perhaps necessary to acknowledge that shortening is a form of editing: it is not done at random, and there is at the very least selection of the parts deemed most salient. Indeed, unedited data may be an impossible ideal: Margarete Sandelowski voices the concern that, in the context of transcription of interviews, what are considered verbatim, unmediated in the study (to whom she dedicated the book) "participated in this study for different reasons. Their main motive was the wish to talk about their own bisexuality, which had directed their life style, emotions and sex drive. But self- interest coincided with social and educational interest. every one of them was concerned about the second-class citizenship accorded to sexual variations." 56

A prima facie reading of this passage may suggest that "bisexuality" was an object "out there" to be investigated, a "property" of the participants ("their own bisexuality"), and certainly the word had been in use for nearly a century; however, it can be argued that the participants' wish to talk about it was not merely to describe a pre-existing object but to constitute bisexuality through discourse, to solidify it into a sexual identity for which battles for education and emancipation could be fought. It is worth considering that the convergence of personal narrative with educational interest and social change as regards the status of sexual minorities could describe Wolff's own life and work, including, as noted, her autobiographical writings. Thus, it can be argued that there was considerable "feedback" between Wolff's "object" of study and herself as inquirer. This feedback was recognized and formulated as an accusation by some reviewers and commentators, highlighting, as noted, the canon of science, whereby investment and feedback are by no means absent but, selectively, either proscribed as bias or "agenda” or made the invisible norm.

\section{Stored Identities, Bisexuality and the Disruption of Binaries}

Writing in 1995, nearly two decades after the publication of Bisexuality, Kenneth Plummer stressed the importance of sexual narratives "in creating change in our intimate lives and our communities," in working toward the attainment of what he terms intimate citizenship, defined as a "cluster of emerging concerns over the rights to choose what we do with our bodies, our feelings, our identities, our relationships, our genders, our eroticisms and our representations.” That these stories are elicited by (or sometimes entrusted to or even thrust upon) social scientists is itself amenable to investigation, and not just because each interview was in many ways unique-as Plummer notes, like Wolff in Bisexuality before him-but because the concern has shifted from "what people say" to "the complex social processes involved in the tellings." These processes include interaction with researchers (Woolgar's "feedbacking”) and the shaping, through the stories, of a personal and com- munity identity or voice that does not pre-exist these narratives (Woolgar's “inversion”). Stories that find a language to be articulated and communicated "through a few tellers and into a community ripe and ready to hear" might coalesce into the formation of an identity-which is, Plummer notes, "the basis of a politics of identity." 57

Thus, Bisexuality, and especially the biographies, provided stories on which the wider "story" of bisexuality as an identity could be built at a time when bisexuality had little visibility and in the face of active suppression by mainstream critics (such as Padel). As Jeffrey Weeks notes, identities "offer narratives of individual life, collective memory and imagined alternatives which provide the motivation and inspiration for change. In that sense, they are not only fictions, they are necessary fictions." " If we consider that, as late as 2000, Bobbie Petford noted that out of seven meters of shelf space labelled "Sexuality" in an unidentified university library, "there were only five centimetres devoted to bisexuality, less than one per cent of the total," it is not surprising that Wolff, working in the seventies, affirmed the value of "fictions" when writing about bisexuality. ${ }^{59}$ On the subjective experience in both male and female participants of "a sense of maleness" or a "sense of femaleness," in Bisexuality she stated that these experiences cannot be verified as "factual," and one might ask whether they are fictitious. But this would not devalue their significance. It can rightly be argued that fiction may be more informative than fact. It can even predict scientific discovery. As we know, the science fiction of today can become the reality of tomorrow. Perhaps the concept of the unconscious itself is fiction. But where would we be without Freud's and Jung's theories which have contributed so much to our understanding of human beings and history? One might also wonder whether certain schools of psychology which claim to be scientific, are but fiction dressed up as science. ${ }^{60}$

Here Wolff questions the assumption of an inherent opposition of "science" and "fiction" by showing their continuity (fiction providing a direction for science) or locating their alleged opposition within rhetorical 
devices (fiction dressed up as science). This troubling of the "science" and "fiction" dichotomy as well as of the attendant implicit hierarchy subverts the received wisdom about the direction of the arrow linking scientific discovery, object, and representation in a similar way to the process of inversion later theorized by Woolgar. It also anticipated critiques of science that would show the continuity of "science" and "fiction," as subsequently articulated by Donna Haraway. ${ }^{61}$

It is worth noting that Wolff was most clearly troubling the "science" and "fiction" binary in a chapter in which she was trying to shed light on the discourses of sexuality underlying the binary of masculinity and femininity and their polarization as sex-bound characteristics: "in every human being, female and male, there are seeds of activity and passivity, extroversion and introversion, spontaneity and reserve, impulsiveness and patience, brutality and tenderness...These human properties have no sex markings.” Wolff offered the proviso that, although she "found necessary to use these terms because they are ingrained in the vocabulary of professionals and laymen [sic] alike," she "would do so with inverted commas." Faute de mieux, she proposed to replace such "ill-conceived notions" with "a sense of male- ness” and "a sense of femaleness," which would shift the emphasis from anatomical sex but be intelligible to those still using the old terms as well as acknowledge their being experienced as "gender identity" from the first- person point of view, whatever the anatomical sex of the individual. Wolff maintained that a bigender identity was the basis of bisexuality, but she cited male transvestites with heterosexual lifestyles as a notable exception in which such "natural bisexuality" was not expressed in a bisexual lifestyle. ${ }^{62}$

Wolff 's conceptualization of bigender identity is close to Sandra Bem's no- tion of androgyny. indeed, Wolff praised Bem for putting forward a model of androgyny with independent dimensions rather than one dimension with two poles, whereby androgyny would be obscured by "masculinity" and "femininity's" reciprocal elision. ${ }^{63}$ yet she did not just adopt Bem's vocabulary: in the course of describing Bem's work on androgyny, Wolff used "psychological hermaphroditism” and "psychological bisexuality” as synonyms within the same paragraph. ${ }^{64}$

As Wolff would subsequently report in the introduction to the second (paperback) edition of Bisexuality released in 1979, she realized after the book's initial publication, from the responses of some reviewers and of many people who attended her lectures and/or who had contacted her, that clarification as to the difference between androgyny and bisexuality was needed. In the new edition, a further autobiography, "Alice," was added to illustrate the difference (as well as the overlap) between bisexuality and androgyny, and in an appendix Wolff explained that both bisexuality and androgyny as they are known in the West have their origins in the myth of Hermaphroditus, but, while "the concept of androgyny is also related to physical appearance, ...bisexuality is not," and while "the word androgyny only applies to human beings, bisexuality...is apparent in the whole of

includes sensual explorations which are special ingredients in homosexual love-making."69 Wolff saw in bisexuality the potential to end (dare we say "queer”?) categorization, but to do so it had to coalesce into an identity, to then "self-destruct" as an identity having fulfilled its potential, as Dennis Altman, writing in 1971, had tentatively envisaged for the category of the "homosexual” and as Joshua gamson would later predict for identity movements vis-à-vis "queer."70 In a categorization-free world, bisexuality would no longer be, in Weeks’s phrase, a “necessary fiction.”71

After the German translation of Bisexuality was published in 1979, an- thropologist Gisela Bleibtreuehrenberg, who around that time had begun a correspondence with Wolff that would continue until Wolff 's death in

1986, wrote a review of the book in the glossy magazine Psychologie Heute (Psychology today) titled "in jedem Mann steckt eine Frau" (in every man exists a woman), which opened with the statement: "Since the sexologist Magnus Hirschfeld discovered a hypothetical 'third sex,' it has taken about seventy years to bring order into the chaos of terms that he originated.” By way of illustration, Bleibtreu-ehrenberg reported an anecdote regarding an exchange she had had ten years before with a well-known jurist who had conflated "intersex" with "homosexual," and she asserted that, after the publication of Bisexuality, which clarified matters, "no one would make such mistakes and aspire to be taken seriously thereafter."72 Far from considering Wolff 's stance “ambiguous,” Bleibtreu-ehrenberg presented Wolff as a taxonomist tracing demarcation lines where confusion reigned. ${ }^{73}$ So, she argued, the chapter on gender identity and sexual orientation should be "compulsory reading for all who deal with transvestism or transsexualism," and she praised Wolff for shedding light "on the categorization of the various sexual deviances ...the bodily as well as the psychological ....and on their different origin." 74

Present-day readers might perhaps disagree about the clarity and consistency of Wolff 's assertions in 
Bisexuality — to quote just one example, the claim that “a mother's favoritism for a son is on a different plane from that for a daughter.

A special closeness and unconscious magnetism draws mother and son together. in extreme cases their bond leads to complete identification which, under circumstances, makes the boy a transsexual.,"75 As noted, the book's unsubstantiated assertions and at times contradictions make it difficult "to appropriate" or to use it strategically for contemporary debates on bisexuality. However, Bleibtreu-ehrenberg's observations highlight how the discussion of bisexuality instantiates binaries (as well as the attendant challenges to binary conceptualization) as regards anatomy, gender identity, and sexual orientation. in order to avoid slipping into essentialism, it is more productive to ask, as Clare Hemmings does, following Sedgwick, "how certain categorizations work, what enactments they are performing and what relations they are creating, rather than what they essentially mean., ${ }^{76}$ Wolff was very aware that the relations discursively produced by sexual categorization in a society in which "normal" is synonymous with "heterosexual" entail inequality and discrimination; in the second edition of the book, she stated: "Nobody would classify anyone of a conventional life style as the heterosexual Mr. or Mrs. Somebody, but a homo- or bisexual person is first and foremost categorized as such. The focus on their 'orientation' is bound to make them acutely selfconscious and ill-at-ease." ${ }^{77}$

The function of the category "bisexuality" would be to reach a "bisexual society" in which gender of sexual object choice would not matter, eradicating the inequality predicated upon discourses of "orientation," and, as noted above, eventually making bisexuality itself, like all categories, obsolete. It can be argued that this is a utopian idea, a vague gesture toward a distant future, remembering the caveat put forward by Angelides, Fox, and Petford that constructions of bisexuality tend to place it in the distant past or in the distant future, precluding its existence in the present. ${ }^{78}$

Furthermore, as "bisexuality" itself is produced through categorization even if en route to ending categorization, and considering the taxonomic endeavor that characterizes especially the introduction to Bisexuality, Wolff 's efforts could be seen as a valiant but ultimately doomed attempt to dismantle the master's house with the master's tools. ${ }^{79}$

Yet the tension between the need to name and story bisexuality into existence- - not least to counteract its routine elision — and the need to go beyond labels as presciently articulated by Wolff in Bisexuality in the seventies is equally contingent today in the context of "queer theory, [which]...problematizes identities," as Meg Barker and Darren Langdridge note. The way through what gamson has called "the queer dilemma" for Barker and Langdridge is by eschewing "either/or" for "both/and," refusing another binary and categorical choice for bisexuality. Barker and Langdridge recognize that "queer theory has much to offer—personally, politically and theoretically," while pointing out the danger that the queer umbrella may create "a new way of silencing bisexuality before it has even found a voice." It would be damaging, they argue, to "leave history lacking a bisexual story." ${ }^{80}$ We contend, in addition, that, in the light of Charlotte Wolff 's work, it would be particularly damaging to leave history neglecting an acknowledgment of her pioneering contribution to theory and research, to "storying" bisexuality into an identity and to the querying and "queering” of categorizations.

Charlotte Wolff 's correspondence quoted with permission of the British Psychological Society. (C) The British Psychological Society. More than thanks can say to graham Richards, Peter dillon-Hooper, Mike Maskill, and everyone at the History of Psychology Centre, British Psychological Society, London. We are indebted to Meg Barker and to Peter Dillon-Hooper for reading an earlier version of this article. Very special thanks to Mick Finlay and Sally Hoadley for their support and to Dublin Bus for providing thinking space atop the number 10 .

${ }^{1}$ Ronald C. Fox, ed., Current Research on Bisexuality (New York: Haworth Press, 2004), 168.

2 Margaret Mead, Coming of Age in Samoa (1928; London: Pelican Books, 1975); Margaret Mead, "Bisexuality: What’s it All About?," Redbook, January 1975, 29-31.

${ }^{3}$ Philip W. Blumstein and Pepper Schwartz, "Lesbianism and Bisexuality," in Sexual Devi- ance and Sexual Deviants, ed. e. goode (New York: Morrow, 1974); Blumstein and Schwartz, "Bisexuality in Women,” Archives of Sexual Behavior 5, no. 2 (1976): 171-81; Blumstein and Schwartz, "Bisexuality in Men," Journal of Contemporary Ethnography [Urban Life] 5, no. 3 (1976): 339-58; Blumstein and Schwartz, "Bisexuality: Some Social Psychological issues," Journal of Social Issues 33, no. 2 (1977): 30-45.

${ }^{4}$ Janet Bode, View from Another Closet: Exploring Bisexuality in Women (New York:

Hawthorn Books, 1976), 14.

${ }^{5}$ Jay P. Paul, "San Francisco’s Bisexual Center and the emergence of a Bisexual Move- ment,” in Bisexualities—the Ideology and Practice of Sexual Contact with Both Men and Women, ed. Erwin J. Haeberle and Rolf gindorf (New York: Continuum, 1998), 130-39; Maggi Rubenstein and Cynthia Ann Slater, “A Profile of the San Francisco Bisexual Center,” Journal of Homosexuality 1, nos. 1-2 (1985): 227-30.

${ }^{6}$ Fritz Klein, The Bisexual Option (New York: Arbor House, 1978); Charlotte Wolff, Bisexuality (1977; London: Quartet Books, 1979).

${ }^{7}$ Steven Angelides, A History of Bisexuality (Chicago: University of Chicago Press, 2001).

${ }^{8}$ Merl Storr, Bisexuality: A Critical Reader (London: Routledge, 1999), 39, emphasis in the original; Sigmund Freud, Three 
Essays on the Theory of Sexuality, trans. James Strachey (1905; London: Penguin, 1977); Ann Kaloski, "Bisexuals Making Out with Cyborgs: Politics, Pleasure, Con/fusion,” Journal of Gay, Lesbian, and Bisexual Identity 2, no. 1 (1997): 47-64.

${ }^{9}$ Clare Hemmings, Bisexual Spaces: A Geography of Sexuality and Gender (London: Routledge, 2002

${ }^{10}$ This tension is evident in many recent writings on bisexuality, for example, Serena Anderlini-d'Onofrio and Jonathan Alexander, eds., Bisexuality and Queer Theory_Intersections, Diversions, and Connections (Binghamton, NY: Haworth Press, 2009), also a special issue of the Journal of Bisexuality 9, nos. 3-4 (2009); Angelides, A History of Bisexuality; Steven Angelides, "Historicizing (Bi)Sexuality: A Rejoinder for gay/Lesbian Studies, Feminism and Queer Theory,” Journal of Homosexuality 52, nos. 1-2 (2006): 12558; Amber Ault, “The dilemma of identity: Bi Women's Negotiations,” in Queer Theory/Sociology, ed. Steven Seidman (Oxford: Blackwell, 1996), 311-30; Meg Barker and Darren Langdridge, "Bisexuality: Work- ing with a Silenced Sexuality," Feminism \& Psychology 18, no. 3 (2008): 389-94; Michael du Plessis, "Blatantly Bisexual: Or, Unthinking Queer Theory,” in RePresenting Bisexualities: Subjects and Cultures of Fluid Desire, ed. Donald e. Hall and Maria Pramaggiore (New York: New York University Press, 1996), 19-54; Mark A. gammon and Kirsten L. isgro, "Troubling the Canon: Bisexuality and Queer Theory," Journal of Homosexuality 52, nos. 1-2 (2006):

159-84; Merl Storr, “Postmodern Bisexuality,” Sexualities 2, no. 3 (1999): 309-25.

${ }^{11}$ Teresa de Lauretis, “Queer Theory: Lesbian and gay Sexualities,” Differences 3 (1991): iii-Xviii.

${ }^{12}$ Freud stated clearly that he found the concept of "bisexual disposition" quite problem-

atic; as Storr notes in his discussion of bisexuality in Three Essays, the footnotes are longer than the main text dealing with bisexuality (Bisexuality, 20). On the whole, Freud considered bisexuality a "primitive" and immature form of sexuality that all individuals are born with and from which heterosexuality (or, sometimes, "homosexuality") will develop (Freud, Three Essays on the Theory of Sexuality, as quoted in Storr, Bisexuality, 22-27). Havelock Ellis’s use of the word "bisexuality” evolved from one in line with early sexology’s usage, denoting the coexistence of male and female anatomical characteristics in the same individual, to describ- ing people who were attracted to both males and females. Ellis found bisexuality puzzling because it called into question the boundary between heterosexual and homosexual. He recognized that a great number of people "who may fairly be considered heterosexual have at some point in their lives experienced a feeling which may be termed sexual toward individu- als of their own sex," and, conversely, homosexual people, with the added incentive of social pressure, might have moved toward heterosexuality. in light of this conundrum, any at- tempt at classification, he wrote, would be devoid of practical use and scientific value (Henry Havelock Ellis, Studies in the Psychology of Sex, vol. 2, Sexual Inversion [1915; Philadelphia: F. A. Davis, 1923], 88). Wilhelm Stekel, a pupil of Freud who eventually fell out with the master, maintained that bisexuality is innate, but around puberty either the homosexual or the heterosexual side is repressed, and this repression can lead to neurosis (Bi-sexual Love [1920; New York: Emerson Books, 1950]).

13 Sara Ahmed, Queer Phenomenology (Durham, NC: duke University Press, 2006); Darren Langdridge, Phenomenological Psychology: Theory, Research and Method (Harlow, UK: Pearson education, 2007); Jonathan Smith, Michael Larkin, and Paul Flowers, Interpreta- tive Phenomenological Analysis: Theory, Method and Research (London: Sage, 2009).

${ }^{14}$ Charlotte Wolff, On the Way to Myself (London: Methuen, 1969).

${ }^{15}$ Charlotte Wolff, Love between Women (London: Duckworth, 1971).

${ }^{16}$ Wolff, Bisexuality, ix.

17 ibid.

${ }^{18}$ Charlotte Wolff, Hindsight (London: Quartet, 1980), 222, 216.

19 As Wolff reported in Hindsight, she began looking for participants for Love between Women in 1967. in November of that year, four months after the decriminalization (in July) of (male) homosexuality for adults over the age of twenty-one in England and Wales (through the Sexual Offences Act of 1967), a mutual friend arranged a meeting between Wolff and gay activist Antony grey, whose campaigning as director of the Albany Trust had played an important role in changing the law. The Albany Trust, founded in 1958 to comple- ment with counselling services and public education initiatives the work of the Homosexual Law Reform Society, still exists and has recently celebrated fifty years of activity (http:// www.albanytrust.org). grey helped Wolff recruit participants and advertised her research in the Albany Trust's newsletter. Other advertisements were placed in the publications of two leading lesbian organizations: the newsletter of Kenric, an organization founded for lesbians in Britain in 1965 (and still active in 2011 , http://www.kenric.org), and Arena Three, the publication of the Minority Research group, the first lesbian organization in the United Kingdom, founded in 1963. Both groups advertised for bisexual participants for Wolff 's new investigation as they had done for her Love between Women study. An advertisement in the bulletin of the Beaumont Society, which since the midsixties had supported transvestites and transsexuals (and still does), also yielded some participants. in addition, Wolff advertised in Gay News, in the magazine Sappho, as well as in the feminist publication Spare Rib and in Time Out, all British publications.

${ }^{20}$ Wolff, Bisexuality, 68.

${ }^{21}$ ibid., 66-67, emphasis in the original.

22 ibid., 69.

${ }^{23}$ ibid., 68.

${ }^{24}$ ibid., 110, 114. Later in the introduction to her last book, a biography of the sexolo- gist and early gay rights campaigner Magnus Hirschfeld, Wolff contrasted a "portrait"-a phenomenological interpretation—of a given "subject” with a cold "“photographic' account of the minutest details of an individual's life and work [that] could never project an image of his personality. A portrait might, with luck, be able to do this” (Magnus Hirschfeld: A Portrait of a Pioneer in Sexology [London: Quartet, 1986], 14).

${ }^{25}$ Wolff, Bisexuality, 114. Wolff, who had a background in (phenomenological) philoso-

phy, seems to foreshadow the move toward reflexivity in (qualitative) research.

${ }^{26}$ ibid., 95.

${ }^{27}$ The term "homoemotional/ity" —emotional affinity for the same sex-was coined by Wolff in Love between Women "to replace the terms lesbian and homosexual" (21); however, as she acknowledged, it would take time for it to become part of the accepted vocabulary - which compelled her to also make use of the old terms. Scholars have subsequently

made use of the concept, including Joanne Trautmann, The Jessamy Brides: The Friendship of

Virginia Woolf and V. Sackville-West (University Park: Pennsylvania State University Press,

1973), 32-33; and Laura A. Markowe, Redefining the Self: Coming Out as Lesbian (London: Blackwell, 1996$), 24$.

${ }^{28}$ Blumstein and Schwartz, "Bisexuality: Some Social Psychological issues."

${ }^{29}$ Wolff, Bisexuality, 95. See above, note 19, on the decriminalization of homosexuality in Britain in 1967. Many male participants had lived in the shadow of the criminalization of homosexuality before the change.

${ }^{30}$ ibid., 93, 96, 95.

${ }^{31}$ See, for example, Paula C. Rust, Bisexuality and the Challenge to Lesbian Politics (New York: New York University Press, 1995); 
Maria gurevich, Jo Bower, Cynthia M. Mathieson, and Bramilee dhayanandhan, “'What do They Look Like and Are They among Us?”: Bisex- uality, (dis)closure and (Un)viability,” in Out in Psychology, ed. Victoria Clarke and Elizabeth Peel (Chichester, UK: Wiley, 2007), 217-41.

${ }^{32}$ Wolff, Bisexuality, 106-7, 109, 106, emphasis in the original.

${ }^{33}$ Matthew Waites, "Sexual Orientation, Human Rights and global Politics," paper pre- sented at the Critical Sexology Seminar “international Approaches to Bisexuality,” London South Bank University, 7 November 2007. An extended version has been published as “Cri- tique of 'Sexual Orientation' and 'gender identity' in Human Rights discourse: global Queer Politics beyond the yogyakarta Principles,” Contemporary Politics 15, no. 1 (2009):

137-56.

${ }^{34}$ Wolff, Bisexuality, “atom bomb” quotation at 109; John Padel, “Normal Bisexuals,” review of Bisexuality, Listener, 2 February 1978, 157. Founded in 1929, the Listener had a long list of distinguished contributors, especially in its early decades, including e. M. Forster, George Orwell, and Julian Huxley, before it ceased publication in 1991. interestingly, the Listener had been perhaps the first UK general publication to give exposure to Wolff 's work in 1937, exactly one year after she had arrived in Britain, with a feature, including three pho- tos, on her research with primate handprints at the London Zoo ("experiment in Science," Listener, 27 October 1937), an article Wolff kept in her CV file, Wol/001/05/01, Charlotte Wolff Archive, History of Psychology Centre, British Psychological Society, London (cited hereafter as HoPC).

${ }^{35}$ Padel, "Normal Bisexuals," 157.

${ }^{36}$ Wolff, Bisexuality, 123.

${ }^{37}$ Charlotte Wolff, “Response to Padel,” reader's letter, Listener, 9 February 1978.

${ }^{38}$ Charlotte Wolff, “Letter to the editor of The Listener,” 5/9 February 1978 (unpub- lished), Wol/001/06/01/01, HoPC, punctuation and underlining as in the original type- script. As regards the date of the letter, there are two draft/carbon copy versions of the letter available in the Wolff archive. One bears the date "5th February, 1978," with handwritten "5th," and is slightly longer, while in the other letter the date is typed, like the rest, as "Feb- ruary 9th 1978." The words quoted in what follows feature in both versions

39 ibid. The psychologist and statistician A. R. Jonckheere (1920-2005) supervised the statistical part of the study, carried out by David Caudrey. As Richard L. Gregory remembers in Jonckheere's obituary, Jonck was generous with his time and expertise, and his name should have appeared as co-author on many more papers than it did, but he eschewed formal recognition (“A. R. Jonckheere," obituary, Guardian, 21 October 2005, 37).

${ }^{40}$ Wolff, "Letter to the editor of The Listener," 5/9 February 1978

${ }^{41}$ Arthur Clark, "Bisexuality," reader's letter, Listener, 16 February 1978; Charlotte Wolff, "Letter to the editor of The Listener," 16 February 1978 (unpublished), Wol/001/06/01/01, HoPC.

${ }^{42}$ Charlotte Wolff, "Letter to George Scott, editor of The Listener,” 27 February 1978

(unpublished), Wol/001/06/01/01, HoPC.

${ }^{43}$ Wolff never held a tenured position, although she had prestigious contacts in academia. in the past, the physicist and psychologist William Stephenson had written a preface to her book The Human Hand (London: Methuen, 1942), but her place in the "House of Science" was always provisional.

${ }^{44}$ Celia Kitzinger, The Social Construction of Lesbianism (London: Sage, 1987), 30

${ }^{45}$ Pierre Bourdieu, The Field of Cultural Production (New York: Columbia University

Press, 1993), 136.

${ }^{46}$ Francis Taylor, “Review of Bisexuality,” Counselling News, December 1977, 29.

${ }^{47}$ Wolff still considered the review "quite good, appreciating the novelty and usefulness of the work, but (it is written by a man) saying that 'feminism' seems to affect dr Wolff 's views in some respects" (Charlotte Wolff, "Reactions to Bisexuality," typed document, 1978 ,

6, Wol/001/06/01/01, HoPC). One of the two copies of this document available in the

Wolff archive is maked (by hand) "rfor Janet" and is dated as "written till April or May 1978.

${ }^{48}$ Kate Millett, Sexual Politics (New York: doubleday, 1970).

49 Wolff, "Reactions to Bisexuality,” 6; Sally Vincent, “Review of Bisexuality,” World Medicine, 25 January 1978, 97-98; Charlotte Wolff, “Response to Vincent,” reader’s letter, World Medicine, 22 February 1978, 15.

${ }^{50}$ Charlotte Wolff, "Letter to the editor of World Medicine," 15 February 1978 (unpub-

lished), Wol/001/06/01/01, HoPC.

${ }^{51}$ Wolff, Bisexuality, 123.

${ }^{52}$ Margarete Sandelowski, "Notes on Transcription,” Research in Nursing and Health

17, no. 4 (1994): 311-14, quotation at 312.

${ }^{53}$ Steven Woolgar, Science: The Very Idea (Chichester, UK: Ellis Horwood, 1988), 32,

36-37, emphasis in the original.

${ }^{54}$ Michel Foucault, The History of Sexuality, vol. 1, An Introduction, trans. Robert Hurley (1976; New York: Random House, 1978);

Jonathan Ned Katz, The Invention of Heterosexu- ality (New York: dutton Signet, 1995).

${ }^{55}$ Woolgar, Science, 65.

${ }^{56}$ Wolff, Bisexuality, 123

${ }^{57}$ Kenneth Plummer, Telling Sexual Stories (London: Routledge, 1995), 17, 13, 128, emphasis in the original.

58 Jeffrey Weeks, "Necessary Fictions: Sexual identities and the Politics of diversity," in Sexualities and Communication in Everyday Life, ed. Karen e. Lovaas and Mercilee M. Jenkins (London: Sage, 2003), 41-54, at 51, originally published in Jeffrey Weeks, Invented Moralities: Sexual Values in an Age of Uncertainty (New York: Columbia University Press/ Cambridge, UK: Polity Press, 1995).

${ }^{59}$ Bobbie Petford, "Power in the darkness: Some Thoughts on the Marginalization of

Bisexuality in Psychological Literature,” Lesbian \& Gay Psychology Review 4, no. 2 (2003):

$5-13$, at 5 .

${ }^{60}$ Wolff, Bisexuality, 56.

${ }^{61}$ donna J. Haraway, Simians, Cyborgs, and Women: The Re-invention of Nature (New York: Routledge, 1991).

${ }^{62}$ Wolff, Bisexuality, 53-54, 34, 54.

63 Sandra L. Bem, “The Measurement of Psychological Androgyny,” Journal of Consult- ing and Clinical Psychology 42, no. 2 (1974): 155-62; Sandra L. Bem, "Sex Role Adapt- ability: One Consequence of Psychological Androgyny,” Journal of Personality and Social Psychology 31, no. 4 (1975): 634-43.

${ }^{64}$ Wolff, Bisexuality, 38. 
${ }^{65}$ Wolff, Bisexuality (1979 edition), viii, 200-201, 202, emphasis in the original.

${ }^{66}$ Wolff, "Letter to the editor of The Listener," 5/9 February 1978.

${ }^{67}$ This exchange took place at a lecture to the South Place ethical Society, Conway Hall, London, 29 November 1977, reported in Wolff, "Reactions to Bisexuality," 3.

${ }^{68}$ Charlotte Wolff, "Bisexuality and Androgyny as the Basic Premise for Understand-

ing Human Beings,” lecture to PeN, London, 2 February 1983 (typed document), 5, Wol/001/06/01/01, HoPC. The correct spelling is hinfällt, but the document was typed using a typewriter with an English keyboard. eve Kosofsky Sedgwick, Epistemology of the Closet (Berkeley: University of California Press), 1.

${ }^{69}$ Wolff, Bisexuality, 64.

${ }^{70}$ Dennis Altman, Homosexual Oppression and Liberation (New York: Outerbridge \& dienstfrey, 1971), 218. interestingly, like Wolff, Altman had considered bisexuality central to the end of categorization: "The vision of liberation that I hold is precisely one that would make the homo/hetero distinction irrelevant. For that to happen, however, we shall all have to recognize our bisexual potential, and until that is done, homosexuality, like blackness, will remain a major category that defines our lives” (ibid.). in the second edition of Bisexu- ality, Wolff included Homosexual Oppression and Liberation in the expanded bibliography, specifying that the book was published in the UK in 1974. Joshua gamson, "Must identity Movements Self-destruct? A Queer dilemma," Social Problems 42, no. 3 (1995): 390-407.

${ }^{71}$ Weeks, "Necessary Fictions."

${ }^{72}$ The German version followed the expanded UK edition of Bisexuality published in

1979; Charlotte Wolff, Bisexualität (Frankfurt: goverts im S. Fischer, 1979). The review is Gisela Bleibtreu-ehrenberg, "in jedem Mann steckt eine Frau," Psychologie Heute (Sep- tember 1980): 82. The German verb stecken has the connotation of "to hide," though the alternative translation, "in every man hides a woman," would unduly "sensationalize" the title of the review. it is worth noting that, although Hirschfeld became associated with the "third sex" in popularizations of his work, he recognized the limitations of this expression and hardly ever used it unqualified. Magnus Hirschfeld, Berlins drittes Geschlecht (1904; Berlin: Rosa Winkel, 1991). See also J. Edgar Bauer, "Magnus Hirschfeld's doctrine of Sexual intermediaries and the Transgender Politics of (No)identity," paper presented at the conference "Past and Present of Radical Sexual Politics," Amsterdam, 2003, available online at http://www.iisg.nl/ womhist/hirschfeld.doc (accessed 1 June 2009); or Toni Brennan and Peter Hegarty, "Who Was Magnus Hirschfeld and Why do We Need to Know?," History and Philosophy of Psychology 9, no. 1 (2007): 12-28.

${ }^{73}$ For a consideration of Wolff 's stance as "ambiguous," see Storr, Bisexuality, 39.

${ }^{74}$ Bleibtreu-ehrenberg, "in jedem Mann,” 82.

${ }^{75}$ Wolff, Bisexuality, 83.

${ }^{76}$ Hemmings, Bisexual Spaces, 8. The original quotation is in Sedgwick, Epistemology of the Closet, 27.

${ }^{77}$ Wolff, Bisexuality (1979 edition), 206.

${ }^{78}$ Angelides, A History of Bisexuality, 17; Ronald C. Fox, "Bisexuality in Perspective: A Review of Theory and Research,” in Bisexuality, ed. B. A. Firestein (Thousand Oaks, CA: Sage, 1996), 3-50, at 4-11; Petford, "Power in the darkness,” 5.

${ }^{79}$ Audre Lorde, Sister Outsider: Essays and Speeches (1984; New York: Crossing, 2007).

${ }^{80}$ Barker and Langdridge, “Bisexuality,” 392. 